\title{
UKRAINIAN DISCOURSE OF APPLIED CULTURAL RESEARCH
}

\section{Kopiyevska O. R.}

\section{INTRODUCTION}

Virtualization of the cultural space and other global consequences have actualized to the Ukrainian scientific community the strengthening of the role and importance of applied research that will solve the problems of the cultural as well as socio-cultural space of Ukraine. The theoretical and practical mobility and transience of cultural transformations determine the need for understanding of modern scientific orientations, modification of their practical results. That is why the need for up-to-date, innovative approaches to the scientific thematization of cultural studies is actualized, which has practical importance for the cultural processes characteristic of Ukraine. The active attention of scientists to contemporary cultural transformation, the invention, and implementation of a practical algorithm for applied research is a theoretical and practical partnership whose mission is to strengthen the role and importance of the results of such a collaboration.

In Ukraine, applied research in cultural knowledge is not an active subject of scientific debate. It should be emphasized that in 2019, in the National Academy of Culture and Arts Management, the first scientific problem, the subject of which is the transformation processes in the cultural practices of Ukraine in their global, glocal, and local dimensions. For the first time in the scientific discourse of cultural studies, the concept of "cultural practices" is thematized, their author's concept is formulated. Based on the analysis of theoretical achievements, it is proved that the thematization of cultural practices in applied cultural studies involves the development of a conceptual-categorical apparatus, which allows you to theoretically substantiate and develop an algorithm for their implementation as a set of actions, techniques, methods, verbal and non-verbal communication, as necessary specifics of spatial locals, topos of their implementation. In the applied dimension, the basic models of transformations of cultural practices are distinguished and characterized: a political model of change, an information model of transformation, the economic model of transformation, the model of transformation of subjectivity, the model of value transformation, the model of transformation in art. It is proved that certain models of transformation actualize the issues of coverage of the dynamics of the development of cultural practices, which requires the conceptualization of the problems of transformation 
processes in the age of globalization and the identification of features of the global and local development of the national cultures ${ }^{1}$.

The study mentioned above is the first attempt of theoretical and methodological substantiation of cultural processes related to transformational changes at the global, glocal, and local levels as well as a determination of the reference field of the objects of study. The development of applied cultural studies in Ukrainian scientific knowledge is promising and timely.

\section{Socio-cultural partnership as an object of research in applied cultural studies}

Current problems of scientific research, understanding the role, value, potential, and resources of the socio-cultural partnership are an essential component of the coexistence and development of cultural spaces, sociocultural cooperation emerges as a crucial consolidating factor for the development of cultural spaces.

Considering partnership as a form of organizational and legal cooperation, we identify its socio-cultural phenomenon, which is not the subject of cultural studies in Ukraine.

The socio-cultural partnership, which involves certain productive activities in the field of culture, that is based not only on normative contractual bases but also on constructive professional dialogue, is of particular relevance. A characteristic feature of the socio-cultural partnership is a well-defined overall mission, in the context of the presented study, it provides for high-quality and effective cultural exchange and result. The socio-cultural partnership is vital in the process of establishing intercultural dialogue, cultural development of Ukrainian cities, meeting the cultural needs of citizens, presenting the uniqueness of urban cultural brands in the world.

The current understanding of socio-cultural partnership is seen as a form of success in the development of the cultural sphere. Socio-cultural collaboration, in its potential, allows attracting a considerable number of stakeholders in the development of the stakeholder culture to increase creativity, innovation, informativeness, multifaceted partnership strategies, proposals, and results.

Ukrainian researcher O. Bezruchko notes that "the phenomenon of sociocultural partnership is the ability to find optimal ways of cooperation with state, public organizations, organically participating in municipal programs as well as with institutions of culture, education, mass media, foundations, etc. and abroad"².

${ }^{1}$ Копієвська О. Р. Трансформаційні процеси в культурних практиках України: глобальний, глокальний контекст та локальні особливості (кінець XX - початок XXI ст.) : дис. ... д-ра культурології : 26.00.06. Київ, 2018. 487 с.

2 Позиціонування і партнерство в сучасній системі соціокультурних комунікацій / Нац. б-ка України для дітей ; автор-уклад. О. В. Безручко. К., 2013. С. 3. 
Considering sociocultural partnership as an intersubjective communicative interaction, voluntary cooperation of interested stakeholders of cultural transformations, participating in joint projects, programs to achieve this goal, we emphasize the importance of exploring the primary mechanisms for its implementation.

While considering the mechanisms of sociocultural partnership, it is necessary to identify and realize each of the partners, their individual and professional interests, mutual contingent potential, namely overcoming particularity and acquiring universality.

The development of sociocultural potential among stakeholders in cultural transformations involves purposeful, systematic activities to transfer a complex of knowledge, skills, abilities, social, cultural values, and ideals.

In this context, we focus on the interdisciplinary value of applied cultural studies, a current understanding of which will allow us to achieve exceptional practical value.

The interdisciplinary nature of partnerships differs in their content. For example, the pedagogy of collaboration, according to T. Kravchinska, includes a system of methods and techniques of education and training based on humanism and creative approach to the development of personality. According to the scientist, "the pedagogy of partnership is based on communication, interaction and cooperation of all stakeholders, united by common goals and aspirations, are voluntary and interested partners, equal participants in the educational process, responsible for the result. Partnership pedagogy defines a genuinely democratic way of cooperation that does not neglect the difference in their life experience, knowledge but implies unconditional equality in the right to respect, trust, goodwill, and mutual demand. ${ }^{3}$ Partnership pedagogy is based on trust, respect for one another, enabling all participants in a partnership to have an open dialogue and to achieve decisive results.

As the essential element of person, the socio-cultural partnership is designed to satisfy different cultural, spiritual, recreational, religious needs of the person, to involve the person in real communication. The socio-cultural collaboration is not an actively discussed category among scholars. The latter's attention is more focused on the notion of "social partnership." Thus, in the scientific literature and practice, social partnership is ambiguous, some understand it as a specific type of social and labor relations between public authorities, the employer and the labor collective, others - more broadly: as a particular type of social relations between professional, social groups, layers, classes, their public associations, authorities and business; as a worldview basis

\footnotetext{
${ }^{3}$ Кравчинська Т. Педагогіка партнерства - основні ідеї, принципи та сутність. URL : lib.iitta.gov.ua/707221/1/Кравчинська_тези.pdf.
} 
for reconciling and protecting the interests of different social groups, classes, classes, their public associations, businesses and authorities. ${ }^{4}$

Priority of scientific topics includes the following: theoretical understanding of socio-cultural partnership, identification of its organizational and legal foundations; identification of socio-cultural components of collaboration in the cultural space of local zones and territories; identification of significant elements of socio-cultural partnership in the system of formation of quality indicators of city culture; study of creative perspectives of socio-cultural partnership; the potential of innovative management initiative in socio-cultural partnership.

Theoretical comprehension of the scientific topics needs to be addressed in terms of their practical implementation.

Thus, in terms of the particular context, we emphasize understanding of educational practices as an essential tool for the effective functioning of sociocultural partnerships.

The development of socio-cultural partnership in the modus operandi is focused on: accessibility of the educational material provided; formation of partnership honesty and trust; focus on professional tolerance; the development of creative thinking in partnerships, the establishment, and conduct of professional (socio-cultural) dialogue.

We observe educational practices as a logically constructed, methodologically meaningful cycle of actions, which includes the development of educational and methodological materials, recommendations for conducting educational clusters in various forms of theoretical knowledge acquisition and implementation of practical tasks, evaluation of their results. The sustainability of educational practices is ensured through the use of both traditional and innovative teaching technologies, copyright techniques, etc.

For example, at the National Academy of Culture and Arts Management, at the Department of Art Management and Event Technologies, within the framework of the realization of the state scientific theme, "Creative Management in the System of Socio-Cultural Development: National and Foreign Practice" (registration Number 0115 U001572), several innovative educational practices have been developed, including educational platforms "Examination of Socio-cultural Event"; an online dictionary of the creative manager of a socio-cultural sphere; a competition program for students of the Cultural Transformation Agents; coaching center of project culture, specialisation of the foreign business language.

To activate and popularize modern applied cultural studies at the department, the opening of the practical Center of Project Culture. The mission

\footnotetext{
${ }^{4}$ Социальное партнерство. URL : http://www.grandars.ru/college/sociologiya/.
} 
of the Center is perspective research in applied cultural studies, project activity in the field of creative cultural industries. The formula of the Center is science + practice + initiative $=$ perspective development .

Principles of the Center: professionalism, equality, responsibility, accessibility, honesty, openness, tolerance, international perspective, functional performance.

The activity of the Center is aimed at solving local socio-cultural, cultural-creative problems, and establishing an international scientific-practical partnership, active grant (project) activity.

The Center has formed a professional expert environment, whose activities are aimed at conducting priority research using author's methods; providing highly qualified expert evaluation of socio-cultural risks and perspectives; development and implementation of educational clusters (coaches, tutors, educators, group mentors), using modern individual and team forms (teambuilding, brainstorming, etc.); developing marketing strategies for the cultural development of local areas and territories; analytical, forward-looking forecasts; advisory activities of all interested stakeholders in cultural transformations; introduction of dual, inclusive, distance education; development of modern managerial strategies and tactics of socio-cultural development (at the glocal and local levels - city, town, region); comprehension of effective algorithms for the implementation of cultural practices (creative industries) in the range from local projects to systematic programs of regional and urban development.

The conducted cultural studies allow us to predict: the current processes of cultural development in Ukraine; future, promising socio-cultural trends and information and communication technologies for the optimization of the cultural industry (cultural practices); modern forms of management modeling; mechanisms for the effective functioning of the core network of cultural institutions, enterprises, institutions and organizations, cultural markets and audiences.

Representatives of the professional expert environment have developed and implemented adequate educational practices that take into account the specifics of professional growth. We understand that the wrong and poorly understood methodology of educational practices leads to specific negative results, namely the lack of synchronization in achieving common goals, the lack of a clear understanding of the potential of socio-cultural partnership; the effectiveness of the equitable distribution of responsibilities; differences within managerial decision making.

Applied cultural studies are of particular relevance during the period of the process of decentralization (transfer of rights, responsibilities, and budgeting from all-Ukrainian state authorities to local ones), which are being actively implemented in Ukrainian reality. 
According to the Law of Ukraine "On Voluntary Association of Territorial Communities," the subjects of voluntary association of territorial communities are adjacent local communities of villages, settlements, cities. In making decisions regarding the voluntary association of regional communities, historical, natural, ethnic, cultural, and other factors that influence the socio-economic development of the united territorial community shall be taken into account. ${ }^{5}$

Thus, territorial communities should imagine their cultural development of their local zones and territories, using both the gained experience and the modern achievements of applied cultural studies, the course of cultural-creative processes, which will allow ensuring perspective socio-cultural and economic development of the united territorial community and thus to promote its cultural thesaurus.

It is an indisputable fact that the role of the scientific and practical potential of socio-cultural partnership between representatives of applied cultural knowledge and contemporary stakeholders of cultural transformations is of exceptional importance. Such a partnership will allow to substantiate and objectively identify the strategic mission and goals of cultural development of the united territorial communities, develop an effective plan of action and implementation, outline its scientifically valid perspective, predict a logical cultural transformation.

In this context, we emphasize the importance of an adequate transformation of educational practices, which implies the flexibility and maximum adaptation to the challenges of today, namely, to prepare a specialist with new professional competencies, capable of decisive management decisions and experiments.

\section{Thematization of the development of competence creativity within applied cultural knowledge}

The world socio-cultural space is characterized by several transformational processes, which in turn have actualized the need for a revision of educational priorities. The question of new approaches to the training of specialists whose professional purpose is to meet the socio-cultural needs of the individual is undeniable.

The modern educational space raises questions about the formation of competencies of future specialists as an essential combination of knowledge, skills, and practical abilities.

${ }^{5}$ Про добровільне об’єднання територіальних громад: Закон України від 04.09.2015 № 676-VIII // Відомості Верховної Ради України. 2015. № 13. Ст. 91. 
In the national higher education glossary, a competency approach is seen as a critical methodological tool for determining learning outcomes based on their description in terms of competencies that underlie a graduate's qualifications. Competencies determine a person's ability to pursue professional and further educational activities successfully. ${ }^{6}$

While generalizing an understanding of the competency approach in higher education, national scholars and experts characterize it as a process of organizing a learning process that should focus on what students learn or can do as a result of learning, rather than what they should learn. At the same time, education is considered as a process which forms students' qualities for the realization of professional activity.

At the same time, the basis for a competent approach is the pursuit of such tasks as: formation of students' qualities necessary for the realization of professional activity, at the request of a modern employer; assessment of the results of contemporary education and their unification and expression in terms and conclusions that can be interpreted and taken into account in any educational institution of any country ${ }^{7}$.

Ukrainian experts in the implementation of the Bologna Process in Ukrainian higher education emphasize that competency development is the goal of curricula that need to be evaluated at different stages. The experts consider the competency approach, the procedures for formulating the names of learning outcomes and competences in their systemic integrity, and identify several levels of description among which are: European meta-qualifications framework, national qualifications framework, sectoral qualifications framework, educational level, discipline level ${ }^{8}$.

Thus, within each specialty, standards are developed following the National Qualifications Framework, which is used to determine and evaluate the quality of content and results of educational activities of higher education institutions.

Among the requirements for educational programs that are defined in the standards are: the volume of ECTS credits required to obtain an appropriate higher education degree; the normative content of training for higher education applicants, formulated in terms of learning outcomes; forms of attestation of applicants for higher education; requirements for having an internal quality

${ }^{6}$ Національний освітній глосарій: вища освіта[Текст]/ ав.-уклад.: В.М. Захарченко, С.А. Калашнікова, В.І. Луговий та ін.; за ред. В.Г. Кременя. - К. : ТОВ Видавничий дім «Плеяди», 2014. С. 28-29.

${ }^{7}$ Компетентнісний підхід у вищій освіті:світовий досвід КНЕУ 2016. С. 14-15. [Електронний ресурс]. - Електорон. дан.- Режим доступу:https://kneu.edu.ua/get_file/5754/.

${ }^{8}$ Рашкевич Ю.М. Болонський процес та нова парадигма вищої освіти: монографія [Текст] / Ю.М. Рашкевич. - Львів: Видавництво Львівська політехніка, 2014. С. 28. 
assurance system for higher education as well as a list of competencies for the graduate. The standards state that the higher education institution independently determines the list of disciplines, practices, and other types of educational activities required to acquire the competency-defined standards. The normative content of the training is determined by the disciplines that ensure the achievement of programmatic learning outcomes. In describing particular disciplines, practices, and other types of learning activities, the purpose of their study (the competences to which this discipline is directed) should be determined and specific planned learning outcomes that will ensure the achievement of programmatic ones. The standards define the percentage of the educational program, which should be aimed at providing general and specialized (professional) competencies in the specialty. The list of skills and program outputs defined in the standards is not exhaustive. Higher education institutions, while forming the profile of educational programs, have the opportunity to identify additional competencies and programmatic learning outcomes that correspond to the variable component of a particular specialization.

The mentioned issue gives us the right to state that the conditions for effective implementation of a competent approach to the preparation of the modern manager of the socio-cultural sphere are created in Ukraine.

Standards for training manager of culture, specialty "Management of socio-cultural activities" have passed a number of discussions with various interested stakeholders (scientists, practitioners), received a number of professional expertise, which in turn allowed to form the necessary professional (particular) competencies that will allow the future work culture taking into account the challenges and time requirements.

Thus, in particular, in the standard of the first bachelor's level, the general competence is defined, which is focused on the ability to generate new, creative ideas, which in turn is reflected in terms of learning outcomes, namely - the identification, generation, and implementation of innovative ideas within professional activity 9 .

To form the competence mentioned above, representatives of the cultural sciences have identified and considered the main thematic blocks that the future specialist of the creative sector in culture needs to carry out their professional duties. The topics of the proposed programs are the result of active cooperation and monitoring of the professional priorities of cultural workers.

${ }^{9}$ Про затвердження стандарту вищої освіти за спеціальністю 028 «Менеджмент соціокультурної діяльності» для першого (бакалаврського) рівня вищої освіти : Наказ Міністерства освіти і науки України від 20.06.2019 № 870. https://mon.gov.ua> 028-menedzhment-sotsiokulturnoi-diyalnosti-bakalavr. 
Acting courses are actively introduced into the educational process for the training of future cultural managers, whose purpose is to gain knowledge of the content, forms, and practical implementation of creative management and cultural innovations in contemporary cultural practices.

Considering the issues of the theoretical discourse of the creative industries in Ukraine, the teaching staff offered content sections, thematic plans, tasks for practical classes, and independent work.

Thus, for the formation of special competences related to the ability to creatively comprehend the cultural and creative perspective of modern development of the sphere of culture, the discipline "Creative Management" was introduced into the educational program for training managers of sociocultural activity, whose task is: mastering the theoretical foundations of creative management culture, creative leadership and motivation; mastering the method of forming a creative socio-cultural space, taking into account the individual and collective needs of all interested stakeholders of cultural transformations.

Logically developed thematic plan and source material of the discipline allows students to form particular (professional) competencies that will ensure a professional future.

The proposed subject of independent work orientates the student to the study of fundamental issues and the development of practical skills in the process of formation, organization, and development of creative cultural industries.

As a result of mastering the course, students should acquire the following competencies:General: knowledge and understanding of the subject area and expertise of professional activity; ability to identify strategic areas of research and work, develop and manage projects; the ability to generate new ideas (creativity); ability to evaluate and ensure the quality of work performed; adherence to the requirements of academic integrity (plagiarism inadmissibility).

- Specialist: development of knowledge and understanding of the basics of creative management and cultural innovations in the field of culture; planning, substantiation and upholding of theoretical value and practical value of own project activity; the use of an interdisciplinary approach in the study and application of creative management and innovation in cultural practices; ability to put into practice the skills and skills in the organization of research, scientific-production works and innovative (creative) projects, in the management of scientific and creative team; ability to develop systems for innovative marketing of socio-cultural products and services; ability to prognostic and project activity in the sphere of culture, modeling of innovative socio-cultural processes and phenomena, identification of tendencies of their development; the ability to provide expertise and provide advisory assistance to a variety of cultural transformation stakeholders. 
The learning outcomes are:

- Knowledge: professional scientific-terminological apparatus; theoretical concepts, scientifically substantiated content, principles, methods, and forms of putting into practice the foundations of creative management and cultural innovation.

- Skills: application of scientific, theoretically sound standards in finding and using information for research work; ability to collect, integrate evidence of own research position and results of creative, innovative practices, present and defend personal opinion on the conducted research; demonstration of analytical thinking skills in professional matters; use of an interdisciplinary approach to solving professional problems, both in research and in practical work; the ability to objectively evaluate and justify the prospects of their own project activities. Possessing of work with primary sources, various educational literature, Internet resources, and more.

The knowledge and skills acquired by the student during the study of the discipline are used in the further study of the following subjects of professional training of a specialist as well as for the development of qualification work.

Thus, to master the adequate tools of creative thinking, the authors of the course paid attention to the issue of representation of creativity in the second scientific and theoretical understanding, which allows the future specialist of the industry to know and understand the subject area of professional activity. The attention is paid to the concept of "creativity," reveals its content, comprehends the basic theoretical approaches to the study, the essence of the concept phenomenon. Particular attention is drawn to the interdisciplinary interpretation of the nature and content of creativity.

Particular attention is paid to the understanding of creativity as an individual psychological trait of a person. Creativity is seen as a form of expression of giftedness, as a professional trait, as an expression of emotional and motivational development. The proposed test tasks allow to form skills to identify common and distinguishing features between the concepts of "creativity" and "intelligence".

Among the unique competencies of exceptional importance are acquiring knowledge of the basics of creative management in the system of management activity. Specifically, topics such as creative management as an innovative organizational and managerial activity; generation of ideas as the primary intention of modern creative management; thematization of creative management in the world's bestsellers.

For the formation of special competencies of the advanced eventmanager, the attention is focused on the issues of creativity as an individual difference of creative (innovative) thinking. Emphasis is placed on the importance of the development of cognitive style and abilities, the role of 
motivation and social influence, forms, and means of expression of individual creativity are determined. Questions of interconnection of such concepts as "giftedness", "madness", "creativity", "innovations" are considered.

Differential specificity of the phenomenon of creativity. The creativity of the group (team). Organizational creativity and innovation: incentives, processability, mechanisms of development, and detection. Methods, tools, and forms of expression of creativity.

For the modern event manager, it is crucial to understand the role and importance, the perspective of creative ideas in the contemporary cultural business space. In particular, the focus is on the success of personalized startups, which are based on creative ideas, innovative management, and marketing; the latter are essential components of creating trending events.

To understand the prospects of creative startups in the professional life of future professionals, special attention is paid to the global, global, and local status of events in the creative industries, the importance of creative thinking in the system of event-image formation of the country, city, town and more. In this context, active attention is drawn to the study of the best world and national cultural practices, their creative expression.

For the formation of special qualitative competences, the following topics are included in the educational process: event service as an object of creative activity and innovative thinking; quality indicators of creative event service; systematicity as an essential component in the organization of an event service; logistics of event services; innovative thinking as a basis in the concept of event service promotion; event agencies in the creative services production system; role play in the system of the preparatory process for the promotion of event services; innovative tools as an essential component of the event agency's personality.

In order to use the professional scientific-terminological apparatus within the practice and to be able to present the results of the completed work and tasks in the educational process, practical tasks are introduced, which allow forming such subsequent learning outcomes as knowledge, skills, communication, autonomy, and responsibility.

For example, for effective implementation of the learning outcomes, a block of topics and practical tasks are offered that allow the formation of sufficient communicative competence of the future specialist. Special attention is paid to the issues of socio-cultural partnership in the system of creative space formation.

Students gain knowledge of the theory of socio-cultural partnership, its missions and goals, core mods, and contemporary challenges.

Practical tasks allow you to develop skills in critical thinking: the role and importance of socio-cultural partnership in creating and promoting a 
successful event; world and domestic practices of socio-cultural cooperation; partnership relations in the modern environment of different socio-age categories (creativity as a form of expression of partnership in the system of cultural needs of people with disabilities, as a sign of socio-cultural adaptation of the elderly; innovative ways of providing cultural adaptation of social categories (ATO participants, multi-child family, etc.)).

Autonomy and responsibility are correlated with understanding and acquiring knowledge of the theory of individual and group motivation, identifying the two dominant components in the creative cultural space. Positive and negative effects of motivation in creativity are investigated; examples of achievements are analyzed; their motivational components are determined.

Understanding the role and importance of motivational diversity in today's event industry will allow future industry professionals to model their individual and group motivational models of creative development. The proposed topic will enable you to autonomously create motivational clusters based on the practices of tutoring, coaching, mentoring, facilitation, advocacy.

The acquisition of knowledge and skills in creative leadership is of utmost importance in the preparation of a modern cultural manager. The theory of innovative leadership will allow you to form a knowledge of effective management practices. The thematization of creative leadership in the cultural industries is on time, and the proposed topic is a focused and driven creative process to create values, ideas, and knowledge. Creative leadership in contemporary culture production emerges as the driving force of business culture. Understanding the characteristics and qualities of a leader, creative leader, understanding the common, and the difference is one of the main competences of the modern culture manager.

Acquisition of knowledge and skills in creative leadership will allow the future specialist to act professionally and responsibly, autonomously managing both their creativity and group.

Issues of a new format of creative leadership in the 21st century are being updated. Thus, it is necessary to have modern techniques and techniques of creative leadership, to understand the business successes of creative leaders in world figures and practices.

Particular attention is paid to mastering the knowledge and practices of modern methods of generating a creative product. We see the topical consideration of issues that reveal the content and perspective of design thinking in the formation of cultural space. The following topics are offered: design thinking as a means of building a creative product; relevance in design thinking; mission and key design thinking factors; the main models and concentration of design thinking in the creative environment; design thinking as 
a tool in making non-standard decisions; design thinking tools; transformational processes of design thinking: results and perspectives.

The previously mentioned factors have allowed us to state that the symbiosis of economic, managerial, and cultural practices within applied cultural studies enables us to implement a systematic and transdisciplinary approach to event management (technology), which is based on the artistic (creative) component. Thus, operating as a basis for carrying out different within complexity and content in term of quantitative and qualitative expert researches, the creative component allows to make situational observations, analyze various information sources, organize and effectively conduct brainstorming sessions, develop both short-term and long-term marketing forecasts, evaluate risks, strategies and event promotions.

\section{CONCLUSIONS}

The mentioned information allows stating the perspective and priority of the development of applied cultural studies in the Ukrainian scientific discourse in the optics of those cultural transformations that are relevant for the contemporary European vector of development of Ukraine.

The use of applied research, a thorough analysis of the current sociocultural processes, a multilevel approach to their regulation, taking into account the dynamic changes of the environment affecting types, models of cultural practices (or cultural industries) allows to: develop new management strategies and tactics of socio-cultural processes at the glocal and local levels - city, village, region), and algorithms for the implementation of cultural practices (creative industries) ranging from local projects to system programs of regional and urban development; to develop and deliver educational cases on applied aspects of cultural institutions management, etc.

The topics of the author's courses (disciplines), allow us to state that in the contemporary cultural knowledge there is an applied understanding of modern forms and means in the preparation of the advanced manager of culture. It should be emphasized that such studies are incomplete and need a broad reflection.

The revitalization of scientific applied cultural practices will allow anticipating not only the issues of formation of professional competencies of the modern cultural manager but also: the current socio-cultural processes in the development of Ukraine; future, prospective trends of the newest, information, and communication technologies of optimization of the cultural industry (cultural practices); opportunities in modern understanding of modeling and management of socio-cultural processes; mechanisms for the effective functioning of the core network of cultural institutions, enterprises, organizations and structures, markets, audiences and cultural practices. 


\section{SUMMARY}

The section discusses the Ukrainian discourse of applied cultural studies, emphasizes the theoretical and practical mobility and transience of cultural transformations, which determines the necessity for the understanding of current scientific orientations, modification of their actual results.

Emphasis is placed on the applied understanding of the content, potential, forms, and mechanisms of socio-cultural partnership. Socio-cultural partnerships, as an object of cultural research, are linked to transformational changes at the global, global, and local levels. The priority of scientific topics includes the theoretical understanding of socio-cultural partnership, identification of its organizational and legal foundations, and components of collaboration in the cultural space. The study of the creative perspectives of socio-cultural cooperation allows us determining the strategic potential of innovative management initiatives. The relevance of the reference field of socio-cultural partnership in Ukrainian scientific knowledge, namely applied cultural studies, is defined.

Emphasis is placed on the actualization of applied research in educational processes, namely the training of modern cultural managers, the formation of their particular (professional) competences. The content and perspective of instructional practices are investigated as a methodologically meaningful cycle of actions, which includes the development of educational and methodological materials, recommendations for conducting clusters in various forms of theoretical knowledge acquisition and implementation of practical tasks, evaluation of their results. The thematization of the development of competence creativity in applied cultural knowledge requires flexibility and maximum adaptation to the challenges of the present, namely - training a specialist with advanced professional competences who would be capable of decisive management decisions and experiments.

\section{REFERENCES}

1. Competency Approach in Higher Education: KNEU World Experience (2016). Retrieved from : https: //kneu.edu.ua/get_file/5754/ [in Ukrainian].

2. Kopiyevska, O. R. (2018). Transformational Processes in the Cultural Practices of Ukraine: Global, Glocal Context and the Local Particularities (the end of XX - the beginning of XXI centuries). Doctor's thesis. Kyiv : NAKKKiM [in Ukrainian].

3. Kravchynska, T. Pedagogy of Partnership - Basic Ideas, Principles and Essence. Retrieved from : lib.iitta.gov.ua/707221/1/Kravchinska_tezi.pdf [in Ukrainian].

4. National educational glossary: higher education (2014). Kremen, V.G. (ed.). Kyiv : Vydavnychyy dim Pleyady [in Ukrainian]. 
5. Positioning and partnership in the modern system of socio-cultural communications (2013). Bezruchko, O.V. (ed.). Kyiv [in Ukrainian].

6. On voluntary unification of territorial communities: Law of Ukraine of 04.09.2015 No. 676-VIII. Bulletin of the Verkhovna Rada of Ukraine. 2015. № 13. Art.91 [in Ukrainian].

7. On approval of the higher education standard in the specialty 028 "Management of socio-cultural activities" for the first (bachelor) level of higher education: Order of the Ministry of Education and Science of Ukraine from 20.06.2019 № 870. Retrieved from : https://mon.gov.ua >028-menedzhmentsotsiokulturnoi-diyalnosti-bakalavr [in Ukrainian].

8. Rashkevych, Yu.M. (2014). The Bologna Process and the New Higher Education Paradigm : A Monograph. Lviv: Lvivska politekhnika [in Ukrainian].

9. Social partnership. Retrieved from : http://www.grandars.ru/ college/sociologiya [in Russian].

\section{Information about the author:} Kopiyevska O. R., orcid.org/0000-0002-4537-4888 Doctor of Cultural Studies, Professor, Head of the Department of Art Management and Event Technologies National Academy of Culture and Arts Management 9, Lavrska str., 01015, Kyiv, Ukraine 